\title{
Jurist-Diction
}

Volume 3 No. 6, November 2020

\section{Penataan dan Pengendalian Pedagang Kaki Lima di Sidoarjo Dalam Pemberdayaan Ekonomi Kerakyatan}

\author{
Bayu Ariefka Ramadhan \\ bayu.ariefka.ramadhan-2015@fh.unair.ac.id \\ Universitas Airlangga
}

How to cite:

Bayu Ariefka Ramadhan,

'Penataan dan Pengendalian Pedagang Kaki Lima di

Sidoarjo Dalam Pemberdayaan

Ekonomi Kerakyatan' (2020)

Vol. 3 No. 6 Jurist-Diction.

Histori artikel:

Submit 1 September 2020;

Diterima 22 September 2020;

Diterbitkan 1 November 2020 .

DOI:

10.20473/jd.v3i6.22958

\begin{abstract}
Abstrak
Penataan dan pengendalian PKL di Sidoarjo dilakukan untuk menciptakan kondisi perekonomian yang tertib dan teratur, sehingga dapat tercapainya kualitas perekonomian rakyat yang baik dan dan akan membantu meningkatkan pendapatan asli daerah. Penelitian ini menggunakan tipe yuridis normatif dengan pendekatan peraturan perundang-undangan dan pendekatan teori. Peneparan peraturan daerah yang telah dikoordinasikan dan disahkan oleh pemerintah pusat untuk mengontrol sebuah kegiatan perekonomian daerahnya secara mandiri. Tindakan penataan PKL oleh pemerintag daerah dilakukan dengan mengutamakan prinsip good governance untuk menjamin keselarasan dalam kegiatan usaha yang dilakukan PKL dan mengantisipasi terjadinya pelanggaran hukum, seperti melakukan usaha dilahan yang tidak sesuai dengan peruntukannya, menimbulkan gangguan bagi pengguna fasilitas umum dan benyaknya limbah yang berasal dari hasil kegiatan usaha yang dilakukan PKL. Penegakan hukum oleh pemerintah daerah dilakukan untuk meningkatkan ketertiban PKL dengan cara persuasif dan represif, yang mana penegakan awal yang dilakukan oleh pemerintah daerah dilakukan dengan cara persuasif yang dilakukan dengan cara pengawasan terhadap pedagang yang melakukan usaha, sedagangkan penegakan represif dilakukan apabila pedagang yang menjalankan kegiatan usaha melakukan pelanggaran dari peraturan yang ada di dalam peraturan daerah.

Kata Kunci: Pengendalian; Pedagang Kaki Lima; Penegakan Hukum; Pemberdayaan Ekonomi Kerakyatan.
\end{abstract}

\section{Pendahuluan}

Indonesia sebagai salah satu negara ASEAN memegang kendali dalam perekonomian skala regional dan internasional. Hal ini terbukti dari semakin menguatnya pekonomian Indonesia dalam menghadapi Masyarakat Ekonomi ASEAN (MEA). Kekuatan ekonomi Indonesia tersebut terbentuk dari keterpaduan dan keselarasan ekonomi regional dan lokal yang saling bersinergi dalam mewujudkan kedaulatan ekonomi Indonesia yang berbasis kerakyatan. 
Pada hakekatnya kedaulatan ekonomi Indonesia yang berbasis kerakyatan tersebut sejalan dengan pencapaian tujuan bernegara sebagaimana tertuang dalam Pembukaan Undang-Undang Dasar Negara Republik Indonesia Tahun 1945 (selanjutnya disebut UUD NRI Tahun 1945) dalam rangka mewujudkan masyarakat yang adil dan makmur. Ketentuan tersebut selanjutnya dijabarkan lebih lanjut dalam peraturan perundangundangan yang mengatur mengenai pemberdayaan ekonomi masyarakat.

Pada hakekatnya kedaulatan ekonomi kerakyatan ini mengandung pengakuan hak-hak warga negara untuk meningkatkan kreativitas dan inovasi dalam menjalankan sebuah kegiatan ekonomi secara mandiri, mendapatkan pekerjaan yang layak serta mendapatkan sebuah imbalan dan perlakuan adil dan layak dalam hubungan kerja sebagaimana diatur dalam Pasal 28 D ayat (2) Undang-Undang Dasar Negara Republik Indonesia Tahun 1945. Sebagaimana hal ini juga diatur dalam Pasal 25 A Undang-Undang Dasar Negara Republik Indonesia Tahun 1945 yang menyatakan bahwa setiap orang berhak untuk hidup serta mempertahankan kehidupannya, hal tersebut menjadi dasar seseorang untuk melakukan kegiatan yang dapat menghasilkan sesuatu yang berguna untuk menjamin kelangsungan hidup mereka. Dengan demikian, seorang dapat melakukan sebuah kegiatan berdagang di suatu wilayah sebagai sarana untuk memenuhi kebutuhan hidup sehari-hari.

Salah satu bentuk penghormatan dan pengakuan hak-hak warganya, pemerintah dan pemerintah daerah mempunyai tanggung jawab untuk memberdayakan pasar tradisional sebagai salah satu kegiatan perdagangan ditengah lajunya arus globalisasi. Hal ini merupakan tantangan bagi pemerintah dan pemerintah daerah untuk mewujudkan demokrasi ekonomi yang ber-kerakyatan dan berkeadilan dalam bingkai Negara Kesatuan Republik Indonesia. Hal ini sebagaimana diatur dalam Pasal 33 ayat (4) Undang-Undang Negara Republik Indonesia 1945 (selanjutnya disebut UUD NRI 1945)

Pasal 33 Ayat (4)

Perekonomian nasional diselenggarakan berdasar atas demokrasi ekonomi dengan prinsip kebersamaan, efisiensi berkeadilan, berkelanjutan, berwawasan lingkungan, kemandirian, serta dengan menjaga keseimbangan kemajuan dan kesatuan ekonomi nasional.****) 
Keberadaan pedagang kaki lima (PKL) dalam pasar tradisional sebagai pasar rakyat yang tumbuh dari ciri khas budaya di Indonesia yang mengedepankan prinsip kerakyatan, kegotongroyongan, dan ke-Bhineka Tunggal Ika, maka sudah sepatutnya untuk dilestarikan dan dipertahankan keberlangsungannya. Dengan mengacu pada Pasal 1 angka 1 Undang-Undang Nomor 20 Tahun 2008 Tentang Usaha Mikro, Kecil, dan Menengah pedagang kaki lima (PKL) termasuk sebagai kelompok usaha mikro yang dimiliki orang perorangan dan/atau badan usaha perorangan yang memenuhi suatu kriteria usaha mikro. Sedangkan dalam Peraturan Menteri Dalam Negeri Nomor 41 Tahun 41 Tahun 2012 tentang Pedoman Penataan dan Pemberdayaan Pedagang Kaki Lima, dijelaskan yang dimaksud pedagang kaki lima adalah orang yang melakukan usaha perdagangan dengan menggunakan sarana usaha bergerak maupun tidak bergerak, menggunakan prasarana kota, fasilitas sosial, fasilitas umum, lahan dan bangunan milik pemerintah dan/atau swasta yang bersifat sementara atau tidak menetap.

Konsep ekonomi kerakyatan tidak bisa dilepaskan dengan konsep kesejahteraan rakyat. Kedua konsep secara implisit dan eksplisit tercantum dalam Pasal 33 ayat (4) UUD NRI Tahun 1945 yang menyatakan bahwa perekonomian nasional diselenggarakan berdasar atas demokrasi ekonomi dengan kebersamaan, efisiensi berkeadilan, berkelanjutan, berwawasan lingkungan, kemandirian, serta dengan menjaga keseimbangan kemajuan dankesatuan ekonomi nasional. Sesungguhnya pasal tersebut menjadi dasar demokrasi ekonomi Indonesia yang mengacu pada pemikiran Mohammad Hatta sebagai wakil presiden kedua pada masa awal kemerdekaan mengenai ekonomi kerakyatan, karena istilah ekonomi kerakyatan memang tidak ditemukan secara eksplisit didalam Undang-Undang Dasar Negara Republik Indonesia Tahun $1945 .{ }^{1}$ Namun demikian secara esensial makna demokrasi ekonomi dimaksud mengacu pada definisi kata "kerakyatan" sebagaimana dikemukakan oleh Mohhamad Hatta dalam tulisannya pada harian Daulat Ra'jat. ${ }^{2}$ Dengan demikian,

1 Revrisond Baswir, Tiada Ekonomi Kerakyatan Tanpa Kedaulatan Rakyat, dalam Baswir (1997), Agenda Ekonomi Kerakyatan (Pustaka Pelajar 2000).[5].

2 ibid. 
ekonomi kerakyatan dapat diartikan sebagai tatalaksana kegiatan perekonomian yang pada penyelenggaraannya memberi dampak kepada kesejahteraan rakyat, yang mana seluruh kegiatan perekonomian dilakukan oleh rakyat kecil.

Demi mewujudkan demokrasi ekonomi atau yang biasa dikenal dengan ekonomi kerakyatan, pemerintah pusat berkoordinasi dengan pemerintah daerah melakukan sebuah kegiatan usaha yang melibatkan rakyat kecil dan menengah, berupa pemberdayaan ekonomi berbasis potensi lokal yang terdapat di daerah tersebut didasarkan pada prinsip desentralisasi dan otonomi daerah yang meligitimasi urusan penyelenggaraan pemerintahan pada Undang-Undang No. 23 Tahun 2014 tentang Pemerintahan Daerah.

Pedagang Kaki Lima yang beroperasi di pusat Kabupaten Sidoarjo berawal dari tahun 2012 yang disebabkan dengan adanya relokasi PKL dari Alun-Alun Kabupaten Sidoarjo yang dipindahkan di Pelataran GOR Sidoarjo. Dirasa lokasi awal yang menunjukan penurunan konsumen, maka mayoritas PKL mencari lokasi berjualan yang dianggap ramai orang melintas sehingga mereka berpindah ke lokasi sepanjang jalan Perumahan Taman Pinang Indah, Kelurahan Lemah Putro yang tidak jauh dari lokasi sebelumnya. Berdasarkan statistik yang diberikan oleh Ibu Cucuk S. jumlah PKL yang menempati Kawasan Taman Pindang Indah pada tahun 2012 sebanyaj kurang lebih 50 orang diberbagai daerah, sehingga semakin bertambah tahun semakin bertambah pula jumlah PKL yang beroperasi dikawasan tersebut. ${ }^{3}$ Yang pada data sejak tahun 2012 hingga 2016 pertumbuhan PKL sangat pesat diwilayah ini, data statistik tersebut dapat dilihat dari tabel berikut: ${ }^{4}$

\begin{tabular}{|cccc|}
\hline No. & Tahun & Jumlah PKL & $\begin{array}{c}\text { \% Kenaikan Dari } \\
\text { Jumlah Mula-Mula }\end{array}$ \\
\hline 1. & 2012 & 50 & - \\
2. & 2013 & 50 & $0 \%$ \\
3. & 2014 & 63 & $26 \%$ \\
4. & 2015 & 81 & $62 \%$ \\
5. & 2016 & 103 & $106 \%$ \\
\hline
\end{tabular}

Sumber: Ibu Cucuk S. Tim Pengurusan Perdagangan Kab. Sidoarjo

3 Wawancara Ibu Cucuk S, dikutip dari http://digilib.uinsby.ac.id/15826/49/Bab\%204.pdf diakses pada Senin 4 Mei 2020. 23:41 WIB.

4 ibid. 
Dengan kegiatan yang telah diakomodir oleh pemerintah pusat maupun pemerintah daerah, unit usaha mikro, kecil, dan menengah seperti pedagang kaki lima (PKL) serta bentuk kegiatan perdagangan yang lain akan dapat berjalan dengan baik dan akan berkembang. Hal tersebut juga tidak dapat terlepas dari aturan-aturan yang telah dibuat agar proses penataan dan pengendalian kegiatan usaha tersebut akan memberikan dampak bagi proses pengembangan ekonomi kerakyatan di daerah. Menyangkut penataan dan pengendalian pedagang kaki lima (PKL) merupakan suatu bentuk usaha pemerintah daerah dalam memaksimalkan potensi-potensi dalam masyarakat agar memiliki legalitas untuk menjalankan suatu usaha.

Mendapatkan pekerjaan dan penghidupan yang layak termasuk dengan melakukan kegiatan usaha informal seperti berdagang merupakan hak konstitusional warga negara yang dijamin oleh Undang-Undang Dasar Negara Republik Indonesia Tahun 1945 yang dijelaskan pada Pasal 27 ayat (2). Terlebih dari sektor informal ini muncul karena ketidakmaksimalan sektor formal dalam menyerap tenaga kerja. Pemerintah memiliki peran sentral, mengingat bahwa Indonesia adalah Negara Hukum yang menjunjung tinggi sifat walfare state, yang mana sejatinya pemerintah bertanggungjawab terhadap kesejahteraan warga negaranya. ${ }^{5}$

\section{Metode Penelitian}

Dalam penelitian ini, menggunakan tipe penelitian yuridis normatif, yaitu tipe penelitian hukum pembahasan pada sebuah norma hukum yang dikaji. Adapun norma hukum ini merupakan asas atau prinsip tingkah laku. Dalam hal ini norma hukum yang akan dikaji khusus mengenai penataan dan pengendalian pedagang kaki lima di Sidoarjo dalam pemberdayaan ekonomi kerakyatan. ${ }^{6}$ Penelitian ini menggunakan statute approach, conceptual approach, dan case approach. Pendekatan ini digunakan untuk menganalisa prinsip-prinsip hukum yang terdapat

${ }^{5}$ Analisa dualistik dan faktor yang menyebabkan sektor ekonomi informal hal. 1-2. Lihat juga konsep Negara Hukum Walfare State oleh Moh. Mahfud M.D., Hukum dan Pilar-Pilar Demokrasi (Gama Media 1999).[129-130].

6 Peter Mahmud Marzuki, Penelitian Hukum: Edisi Revisi (Kencana 2009).[54]. 
dalam keabsahan penegakan hukum administrasi untuk mengikat secara hukum yang dikaitkan dengan penataan dan pengendalian pedagang kaki lima (PKL) sebagai bentuk social control.

\section{Keabsahan Tindakan Pemerintah Daerah Dalam Melakukan Penataan dan Pengendalian PKL}

Pada hakekatnya penataan dan pengendalian PKL merupakan upaya sturent dalam konsep hukum administrasi dalam rangka mewujudkan kesejahteraan dan ketertiban umum masyakat sebagaimana tertuang dalam tujuan negara dalam Pembukaan UUD NRI Tahun 1945. Atas hal tersebut untuk meminimalisir terjadinya penyalahgunaan wewenang dalam penataan dan pengendalian PKL, maka perlu adanya guidance bagi Pemerintahan Daerah dalam penyelenggaraan pemerintahan daerah tersebut. Dalam hal ini salah satunya adalah terkait keabsahan tindakan pemerintahan dalam penataan dan pengendaliaan PKL.

Terkait keabsahan tindakan pemerintahan dalam penataan dan pengendalian PKL ini meliputi wewenang, substansi dan prosedur. Keabsahan tindakan pemerintahan tersebut dengan mengacu pada Undang-Undang No. 23 Tahun 2014 tentang Pemerintahan Daerah dan Undang-Undang No. 30 Tahun 2014 tentang Administrasi Pemerintahan.

\section{Kewenangan Pemerintah Dalam Melakukan Penataan dan Pengendalian Pedagang Kaki Lima}

Undang-Undang No. 23 Tahun 2014 tentang Pemerintahan Daerah(selanjutnya disebut UU No. 23 Tahun 2014) sangat jelas mengatur mengenai pembagian urusan penyelenggaraan pemerintahan sebagai realisasi dari asas otonomi daerah. Otonomi daerah memberikan konsekuensi pada setiap daerah untuk mengatur dan mengurus rumah tangganya sendiri sesuai dengan kewenangannya sebagaimana diatur dalam peraturan perundang-undangan yang berlaku.

Terkait dengan kewenangan pemerintah dalam melakukan penataan dan pengendalian pedagang kaki lima hal ini tentunya harus mengacu pada UU No. 23 
Tahun 2014 sebagai realisasi asas legalitas dan asas negara hukum. Negara Kesatuan Republik Indonesia adalah Negara hukum (rechtstaat). Syarat-syarat rechtsstate yang dikemukakan oleh Burknes.et.al., yang dikutip Philipus M. Hadjon dalam tulisannya tentang Ide Negara Hukum dalam Sistem Ketatanegaraan Republik Indonesia adalah sebagai berikut:

1) Asas legalitas: setiap tindakan pemerintahan harus didasarkan atas adasar peraturan perundang-undangan (wetterlike grodslag). Dengan landasan ini, undang-undang dalam arti formal dan UUD sendiri merupakan tumpuan dasar tindak pemerintahan. Dalam hubungan ini pembentuk undang-undang merupakan bagian penting negara hukum.

2) Pembagian kekuasaan: syarat ini mengandung makna bahwa kekuasaan negara tidak boleh hanya bertumpu pada satu tangan.

3) Hak-hak dasar (grondrechsten): hak-hak dasar merupakan sasaran perlindungan hukum bagi rakyat dan sekaligus membatasi kekuasaan pembentukan undang-undang.

4) Pengawasan Pengadilan: bagi rakyat tersedia saluran melalui pengadilan yang bebas untuk menguji keabsahan tindak pemerintahan (rechtmatigheids toetsing) ${ }^{7}$.

Atas hal tersebut sebagai implementasi dari negara hukum, kebijakan dan kewenangan pemerintah dalam pengelolaan terhadap pengendalian dan penataan PKL harus sedasar dengan asas legalitas. Selain itu penghormatan dan penghargaan terhadap hak-hak masyarakat untuk meningkatkan kesejahteraannya dengan bekerja dalam usaha menengah dan kecil, serta pedagang kaki lima. Oleh karenanya setiap kebijakan yang diambil oleh pemerintahan daerah juga harus sesuai dan selaras dengan kewenangannya sesuai dengan pembagian urusan pemerintahan untuk meminimalisir terjadinya penyalahgunaan wewenang.

Konsep wewenang dalam penyelenggaraan pemerintahan sudah sepatutnya dipahami sebagai salah satu guidance dalam melakukan tindakan pemerintahan. Konsep wewenang merupakan salah satu elemen dari asas keabsahan bagi pemerintah dalam melakukan tindakan pemerintahan. Konsep wewenang ini merupakan konsep inti dalam Hukum Tata Negara dan Hukum Administrasi sebagai hukum publik untuk media social control dalam penyelenggaraan pemerintahan. Wewenang dijelaskankan sebagai kekuasaan hukum (rechtsmacht) sehingga wewenang

7 Philipus M. Hadjon, Ide Negara Hukum, (Makalah yang disampaikan pada Seminar Hukum Administrasi, Fakultas Hukum Universitas Airlangga 2004).[4]. 
senantiasa erat berkait dengan kekuasaan pemerintah (negara). Konsep wewenang ini dalam pendekatan hukum admnistrasi termasuk dalam pendekatan kekuasaan, hal ini bermakna dalam pendekatan kekuasaan itu menjelaskan bahwa kekuasaan dan kewenangan yang dimiliki oleh Pemerintah dalam penyelenggaraan pemerintahan harus dapat diunjukkan dasar hukumnya. Wewenang sekurang-kurangnya terdiri dari 3 (tiga) komponen yaitu: pertama, Pengaruh; kedua, Dasar hukum; ketiga, Konformitas hukum. Ketiga hal tersebut merupakan parameter pemerintah dalam melaksanakan tugas dan kewajiban yang sudah menjadi kewenangannya. ${ }^{8}$

Dalam konteks penerbitan izin yang di peruntukkan bagi pedagang kaki lima (PKL) pemerintah wajib memperhatikan hak-hak yang dimiliki oleh para pedagang, namun disaat yang bersamaan pemerintah juga memiliki hak untuk melakukan penegakan hukum yang didasarkan pada peraturan daerah yang berlaku. Suatu usaha pemerintah daerah adalah dengan melakukan pemberdayaan usaha mikro, kecil dan menengah (UMKM) melalui pendataan, kemitraan, kemudahan perizinan bagi pedagang yang telah memenuhi persyaratan, penguatan kelembagaan yang menaungi para pedagang agar mendapat legalitas dalam melakukan usaha, dan melakukan suatu koordinasi dengan pihak-pihak yang bersinggungan langsung dengan kegiatan usaha yang melibatkan masyarakat umum.

Terdapat pembagian urusan pemerintahan yang mengerjakan bidang koperasi, usaha kecil dan menengah. Hal itu dijelaskan sebagai berikut :

\begin{tabular}{|c|c|c|c|c|}
\hline No. & Sub Urusan & Pemerintah Pusat & Daerah Provinsi & $\begin{array}{l}\text { Daerah } \\
\text { Kabupaten/Kota }\end{array}$ \\
\hline 1. & $\begin{array}{l}\text { Pemberdayaan } \\
\text { Usaha Menengah, } \\
\text { Usaha Kecil dan } \\
\text { Usaha Mikro } \\
\text { (UMKM) }\end{array}$ & $\begin{array}{l}\text { Pemberdayaan } \\
\text { usaha menengah } \\
\text { dilakukan melalui } \\
\text { pendataan, } \\
\text { kemitraan, } \\
\text { kemudahan } \\
\text { perijinan, } \\
\text { penguatan } \\
\text { kelembagaan dan } \\
\text { koordinasi dengan } \\
\text { para pemangku } \\
\text { kepentingan }\end{array}$ & $\begin{array}{l}\text { Pemberdayaan usaha } \\
\text { kecil yang dilakukan } \\
\text { melalui pendataan, } \\
\text { kemitraan, } \\
\text { kemudahan } \\
\text { perijinan, penguatan } \\
\text { kelembagaan dan } \\
\text { koordinasi dengan } \\
\text { para pemangku } \\
\text { kepentingan }\end{array}$ & $\begin{array}{l}\text { Pemberdayaan } \\
\text { usaha mikro } \\
\text { yang dilakukan } \\
\text { melalui pendataan, } \\
\text { kemitraan, } \\
\text { kemudahan } \\
\text { perijinan, penguatan } \\
\text { kelembagaan dan } \\
\text { koordinasi dengan } \\
\text { para pemangku } \\
\text { keprntingan }\end{array}$ \\
\hline
\end{tabular}




\begin{tabular}{|c|c|c|c|c|}
\hline 2. & $\begin{array}{l}\text { Pengembangan } \\
\text { UMKM }\end{array}$ & $\begin{array}{l}\text { Pengembangan } \\
\text { usaha menengah } \\
\text { dengan orientasi } \\
\text { peningkatan skala } \\
\text { usaha menjadi }\end{array}$ & $\begin{array}{l}\text { Pengembangan } \\
\text { usaha kecil dengan } \\
\text { orientasi peningkatan } \\
\text { skala usaha menjadi } \\
\text { usaha menengah }\end{array}$ & $\begin{array}{l}\text { Pengembangan } \\
\text { usaha mikro } \\
\text { dengan orientasi } \\
\text { peningkatan skala } \\
\text { usaha menjadi }\end{array}$ \\
\hline
\end{tabular}

Sumber: Undang-Undang Nomor 23 Tahun 2014 Tentang Pemerintahan Daerah.

\section{Jenis Tindakan Pemerintah Dalam Melakukan Penataan dan Pengendalian Pedagang Kaki Lima}

Pada hakekatnya tindakan pemerintahan dalam melakukan penataan dan pengendalian PKL termasuk tindakan hukum publik. Hal ini dikarenakan tindakan Pemerintahan tersebut termasuk dalam urusan penyelenggaraan tindakan pemerintahan sebagaimana tertuang dalam UU No. 23 Tahun 2014 tentang Pemerintahan Daerah dan Undang-Undang No. 25 Tahun 2009 tentang Pelayanan Publik. Dalam hal ini tindakan pemerintahan ini bertujuan untuk melakukan pengendalian dalam rangka tercapainya tujuan negara yakni mewujudkan kesejahteraan masyarakat umum sebagaimana tertuang dalam Pembukaan UUD NRI Tahun 1945.

Kegiatan usaha kecil seperti pedagang kaki lima(PKL) dan beberapa pedagang kecil yang lainnya di pasar tradisional, merupakan bentuk usaha masyarakat kecil yang berusaha untuk mendapatkan pemenuhan ekonomi secara mandiri dan kreatif. Perlu dipahami bahwa usaha mikro, kecil dan menengah (UMKM) memainkan peran penting dalam pembangunan dan pertumbuhan ekonomi, tidak hanya di negara-negara sedang berkembang, tetapi juga di negara-negara maju. Selain itu ekonomi kerakyatan dari usaha mikro, kecil dan menengah (UMKM) merupakan supporting utama kegaiatan ekonomi suatu negara. ${ }^{9}$

Kegiatan usaha kecil merupakan cerminan dari kegiatan ekonomi masyarakat bawah yang tetap berjalan dalam lingkup perekonomian mandiri, yang sering dilakukan perorangan dengan skala kecil. Dalam hal ini secara umum dimaksud

${ }^{9}$ Tulus Tambunan, Usaha Mikro, Kecil, dan Menengah Di Indonesia: Isu-Isu Penting, (LP3ES 2012).[1]. 
dengan usaha kecil perorangan adalah usaha yang memenuhi syarat-syarat dan karakter sebagai berikut, yakni usaha tersebut bukan merupakan badan hukum atau persekutuan. Kemudian diurus dan dijalankan atau dikelola oleh pemiliknya atau dengan memperkerjakan anggota keluarganya yang terdekat dakam skala kecil. Selain itu keuntungan perusahaan benar-benar hanya sekedar untuk memenuhi nafkah hidup sehari-hari pemiliknya. Dalam hal ini bentuk setiap usaha dagang tersebut yakni berkeliling, pedagang pinggir jalan, atau pedagang kaki lima (PKL). ${ }^{10}$

Dalam penyelenggaraan pemerintahan Pemerintah melakukan dua macam tindakan, tindakan biasa dan tindakan hukum. Dalam kajian hukum, yang terpenting untuk dikemukakan adalah tindakan dalam kategori tindakan hukum. Tindakan hukum pemerintah adalah tindakan yang dilakukan oleh Badan atau Pejabat Tata Usaha Negara dalam rangka melaksanakan urusan pemerintahan. Tindakan hukum pemerintah itu dibagi menjadi dua macam, yaitu hukum publik dan hukum privat. Perbuatan hukum publik dibagi menjadi dua, yaitu hukum publik bersegi satu dan hukum publik bersegi dua. Perbuatan hukum publik bersegi dua dibagi menjadi perjanjian dan tindakan bersama. Tindakan hukum publik tersebut harus sedasar dengan peraturan perundang-undangan sebagai realsisasi asas negara hukum. ${ }^{11}$

Tindakan hukum publik menurut Bellefroid adalah hukum yang mengatur cara badan-badan negara menjalankan tugasnya dan mengatur pula hubungan hukum yang diadakan negara sebagai pemerintah dengan para individu atau yang diadakan antara masing-masing badan negara itu. Dalam hal ini tindakan hukum publik dalam ranah mewujudkan kewajiban negara dalam penyelenggaraan pelayanan publik. ${ }^{12}$ Sedangkan tindakan hukum privat menurut Bellefroid adalah hukum yang mengatur tara tertib masyarakat mengenai keluarga dan kekayaan individu dan mengatur pula hubungan-hubungan yang diadakan antar para individu dan mengatur pula hubungan-hubungan yang diadakan antar para individu satu dengan yang lain, antar individu dengan badan negara. Dalam hal ini unsur perjanjian memegang kendali

\footnotetext{
${ }^{10}$ Richard Burton Simatupang, Aspek Hukum Dalam Bisnis (Rineka Cipta 1996).[195-196].

11 Jum Anggriani, Hukum Administrasi Negara (Graha Ilmu 2012).[106].

12 ibid.[108].
} 
penting dalam ranah tindakan pemerintah yang bersifat privat. ${ }^{13}$

Pada hakekatnya setelah memehami konsep tindakan hukum pemerintah di atas, selanjutnya dapat kita tarik unsur-unsur yang terdapat dalam tindakan hukum pemerintah untuk menangani semakin maraknya pedagang kaki lima (PKL) adalah:

1. Perbuatan itu dilakukan oleh aparat pemerintahan dalam kedudukannya sebagai alat pemerintahan dengan prakarsa dan tanggungjawab sendiri;

2. Perbuatan tersebut dilaksanakan dalam rangka menjalankan fungsi pemerintahan;

3. Perbuatan tersebut dimaksudkan sebagai sarana untuk menimbulkan akibat hukum dibidang hukum administrasi;

4. Perbuatan tersebut menyangkut pemeliharaan kepentingan negara dan rakyat;

5. Perbuatan itu harus didasarkan pada peraturan perundang-undangan yang berlaku. $^{14}$

Dalam praktiknya urusan pemerintahan tidak dijalankan sendiri oleh pemerintah, namun dijalankan pula oleh pihak-pihak lain bahkan juga pihak swasta yang diberikan wewenang untuk menjalankan urusan pemerintahan dalam kerangka hubungan kerjasama. Menurut E. Utrech tindakan pemerintah itu dapat dilakukan dengan berbagai cara, yaitu :

1. Dalam hal ini yang bertindak ialah administrasi negara sendiri;

2. Yang bertindak ialah subjek hukum (sama dengan badan hukum) lain yang tidak termasuk administrasi Negara dan yang mempunyai hubungan istimewa atau hubungan biasa dengan pemerintah;

3. Yang bertindak ialah subjek hukum lain yang tidak termasuk administasi Negara dan menjalankan pekerjaannya berdasarkan suatu konsesi atau berdasarkan izin (vergunning) yang diberikan oleh pemerintah;

4. Yang bertindak ialah subjek hukum lain yang tidak masuk administrasi negara dan yang diberi subsidi pemerintah;

5. Yang bertindak ialah pemerintah bersama-sama subjek hukum lain yang bukan administrasi negara dan kedua belah pihak itu bergabung dalam bentuk kerjasama (vorm van samenwerking) yang diatur oleh hukum privat;

6. Yang bertindak ialah yayasan yang didirikan oleh pemerintah atau diawasi oleh pemerintah;

7. Yang bertindak ialah subjek hukum lain yang bukan administrasi Negara tetapi diberi suatu kekuasaan memerintah (dilegasi perundang-undangan). ${ }^{15}$

\footnotetext{
13 ibid.[106-107].

14 Ridwan HR, Hukum Administrasi Negara (Rajawali Pers 2016).[112].

15 Ridwan HR. Hukum Administrasi Negara (Rajawali Pers 2016).[121-122].
} 
Terkait dengan tindakan pemerintah di atas, keputusan pemerintah berupa Izin merupakan salah satu tindakan pemerintah yang menjadi sarana pengendalian terhadap tingkah laku warga masyarakat, oleh karena itu sebagai tindakan pemerintah izin harus memenuhi asas keabsahan. Salah satu asas keabsahan yang harus dipenuhi adalah wewenang. Ruang lingkup penggunaan wewenang itu memiliki 3 (tiga) elemen, yaitu : ${ }^{16}$

a. Mengatur

Kewenangan mengatur berkaitan dengan tugas pemerintah dalam menjalankan fungsi mengatur, sesuai dengan fungsi tersebut kewenangan pemerintah mengeluarkan izin digunakan untuk mengatur tingkah laku warga agar suatu kegiatan tidak mengganggu warga lain.

b. Mengontrol

Kewenangan melakukan kontrol terhadap kehidupan masyarakat sangat berkaitan dengan tugas pemerintah yang berhubungan dengan tugas mengatur, dimana mengadakan pembatasan-pembatasan tertentu kepada aktifitas masyarakat di bidang sosial, ekonomi, maupun bidang politik. Kewenangan mengontrol dimaksudkan agar masyarakat dapat lebih terarah dalam melakukan sebuah aktifitas, sehingga tidak menyimpang dari ketentuanketentuan larangan atau perintah yang diberikan oleh pemerintah berdasarkan peraturan hukum yang ada. Dengan demikian dalam menetapkan izin sebagai sarana yang digunakan untuk mengendalikan aktifitas masyarakat tidak hanya berhenti dalam menetapkan izin saja tetapi pemerintah memiliki kewenangan untuk melakukan kewenangan mengontrol agar izin dapat dilaksanakan sesuai dengan persetujuan tersebut.

c. Pemberian sanksi atau penegakan hukum

Kewenangan untuk memberikan sanksi sangat dominan dalam bidang hukum administrasi oleh karena itu tidak ada manfaatnya bagi pejabat pemerintah dilengkapi kewenangan mengatur dan kewenangan mengontrol tanpa ada

${ }^{16}$ Tatiek Sri Djatmiati, Prinsip Izin Usaha Industri di Indonesia (Disertasi, Program Pascasarjana Universitas Airlangga 2004).[75]. 
kewenangan untuk menerapkan sanksi. Di dalam menjalankan fungsi mengatur, pemerintah memerlukan sarana "pemaksa" agar aturan-aturan hukum yang dibentuk dapat dipatuhi dengan baik oleh warga masyarakat. Demikian halnya dengan menetapkan izin sebagai kewenangan mengatur yang dimiliki pemerintah tidak akan bermanfaat tanpa adanya kewenangan mengontrol dan kewenangan penegakan hukum.

\section{Perizinan Usaha Bagi Pedagang Kaki Lima (Prosedur. Persyaratan dan Jenis}

\section{Izinnya)}

Kegiatan usaha yang dilakukan oleh masyarakat berupa usaha mikro, kecil, dan menengah (UMKM) perlu memdapatkan sebuah bentuk legalitas yang diterbitkan oleh pemerintah daerah. Sebuah perizinan usaha wajib didapatkan oleh masyarakat yang ingin melakukan kegiatan usaha, baik yang dilakukan di tempat tinggal pribadi maupun yang menggunakan fasilitas milik pemerintah daerah. Dalam hal ini pemerintah daerah berkoordinasi dengan koperasi yang dibentuk untuk menaungi masyarakat yang berwirausaha untuk membantu bersinergi dengan pedagang kaki lima (PKL).

Menurut Peraturan Presiden Nomor 98 Tahun 2014 Tentang Prizinan untuk Usaha Mikro dan Kecil pada pasal 1 butir 3 menjelaskan bahwa izin usaha mikro dan kecil yang selanjutnya disingkat dengan IUMK adalah tanda legalitas kepada seseorang atau pelaku usaha atau kegiatan tertentu dalam bentuk izin usaha mikro dan kecil dalam bentuk satu lembar dan IUMK dimaksudkan untuk memberikan kepastian hukum dan sarana pemberdayaan bagi pelaku usaha mikro dan kecil dalam mengembakan usahanya.

Dalam mengurus Izin Usaha Mikro dan Kecil (IUMK) sebagaimana diatur dalam Pasal 7 ayat (2) Peraturan Menteri Dalam Negeri Republik Indoneisa No. 83 Tahun 2014 Tentang Pedoman Pemberian Izin Usaha Mikro, Kecil dan Menengah wajib menjalankan prosedur yang sebagai berikut :

1. Surat pengantar dari aparat di lingkungan seperti RT/RW yang berhubungan dengan pembangnan usaha, 
2096 Bayu Ariefka: Penataan dan Pengendalian

2. Fotocopy dan dokumen Kartu Tanda Penduduk asli,

3. Fotocopy dan dokmen Kartu Keluarga asli,

4. Dua lembar foto berukuran $4 \times 6 \mathrm{~cm}$.

Jika memenuhi semua dokumen tersebut, maka terdapat formulir IUMK yang disediakan. Isi dari formulir tersebut untuk dengan segala data yang dibutuhkan, serta pengisian modal usaha dan tempat melakukan usaha. Berikut ini adalah skema penerbitan Izin Usaha Mikro dan Kecil :

Tabel $1^{17}$

Persyaratan :

1. Surat Pengantar RT/RT;

2. Kartu Tanda Penduduk Asli;

3. Kartu Keluarga Asli;

4. Pas Foto 2 lembar $(4 \times 6 \mathrm{~cm})$

Mengisi formulir :

1. Nama

2. Nomor KTP

3. Nomor Telepon

4. Alamat Usaha

5. Kegiatan Usaha

6. Sarana yang digunakan

7. Jumlah Modal Usaha

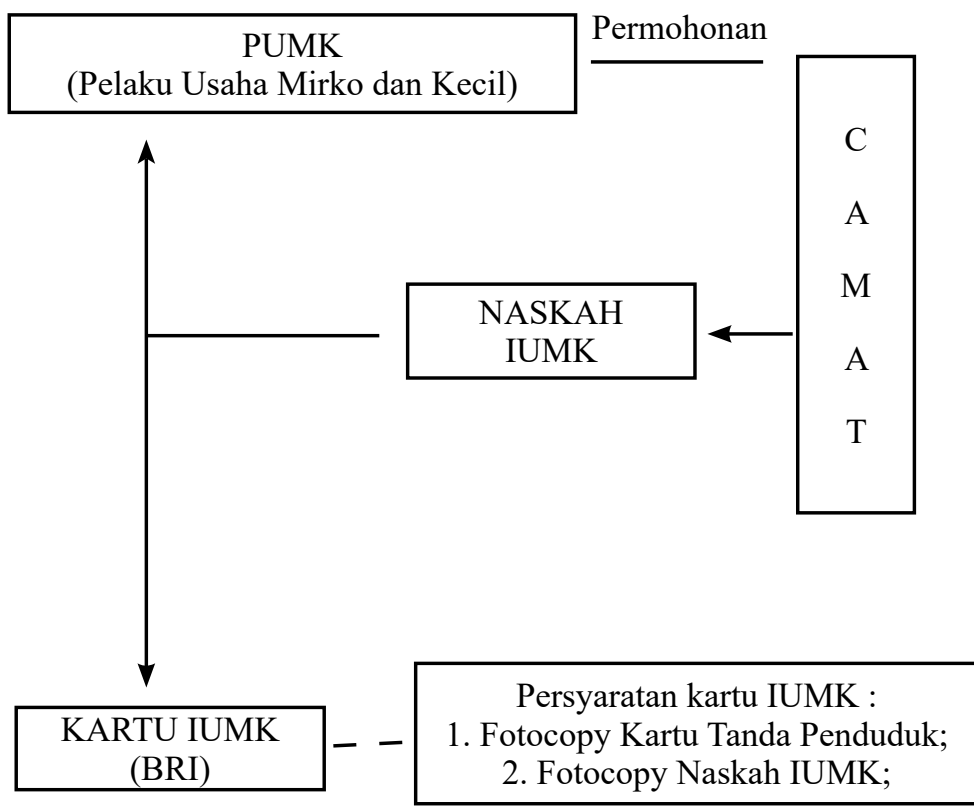

Dalam hal ini usaha mikro adalah badan usaha perorangan yang memiliki kriteria sesuai dengan Pasal 6 ayat (1) dan ayat (2) Undang-Undang (UU) Nomor 20

Tahun 2008 Tentang Usaha Mikro, Kecil dan Menengah, yaitu :

a. Memiliki asset atau kekayaan bersih hingga $\mathrm{Rp} 50.000 .000$,- tidak termasuk tanah atau bangunan tempat usaha;

b. Omzet penjualan tahunan hingga Rp 300.000.000,-.

${ }^{17}$ Ike Nofalia, S.Kom., Mekanisme Penerbitan Surat Izin Usaha Mikro Kecil, https://www. finansialku.com/surat-izin-usaha-mikro-kecil/, diakses pada tanggal 01 Juni 2020 jam 07.00 WIB. 
Sementara, berdasarkan perkembangannya, usaha mikro diklasifikasikan menjadi dua, yaitu :

1. Livelihood, yaitu usaha mikro yang sifatnya untuk mencari nafkah semata. Jenis usaha mikro yang satu ini dikenal luas sebagai sektor informal. Contohnya aalah pedagang kaki lima (PKL)

2. Micro, yaitu usaha mikro yang sudah cukup berkembang, namun memiliki sifat kewirausahaan dan belum bisa menerima pekerjaan subkontraktor serta belum bisa melakukan kegiatan ekspor. ${ }^{18}$

Pasal 3 ayat (1) Peraturan Presiden Republik Indonesia Nomor 125 Tahun 2012 Tentang Koordinasi Penataan dan Pemberdayaan Pedagang Kaki Lima yang menjelaskan beberapa kewenangan yang dimiliki oleh pemerintah daerah dalam usaha penataan dan pemberdayaan pedagang kaki lima, yaitu:
a. Pendataan dan pendaftaran PKL;
b. Penetapan lokasi PKL;
c. Pemindahan dan Penghapusan lokasi PKL;
d. Peremajaan lokasi PKL;
e. Perencanaan penyediaan ruang bagi kegiatan PKL.

Pendataan dan pendaftaran pedagang kaki lima (PKL) dapat berupa tempat berjualan, jenis tempat usaha, bidang usaha, modal usaha yang dimiliki oleh pedagang kaki lima, dan volume penjualan. Usaha pemerintah ini didasarkan pada beberapa asas, yaitu :
a. Kemanusiaan;
b. Keadilan;
c. Kemitraan;
d. Kepastian hukum;
e. Kelestarian lingkungan;
f. Kejujuran usaha; dan
g. Persaingan sehat.

Pemerintah memiliki tujuan dengan adanya usaha penataan dan pengendalian ini, pedagang kaki lima dapat memiliki kesempatan melakukan kegiatan usaha melalui penetapan lokasi yang sesuai dengan peruntukannya, menumbuhkan dan

${ }^{18} \mathrm{Nn}$, Usaha Mikro: Klasifikasi, Dasar Hukum dan Kewajiban Perpajakan, https://www. online-pajak.com/usaha-mikro, diakses pada 12 Februari 2020. 
mengembangkan kemampuan usaha pedagang kaki lima menjadi usaha ekonomi mikro yang tangguh dan mandiri, dan mewujudkan kawasan kota yang bersih, indah, tertib dan aman dengan sarana dan prasarana kawasan yang memadai dan berwawasan lingkungan.

Selain kewenangan dalam membentuk sebuah regulasi, pemerintah daerah memiliki kewajiban untuk melakukan monitoring, evaluasi, dan pelaporan terhadap kegiatan penataan dan pemberdayaan pedagang kaki lima (PKL). Menurut Pasal 32 Peraturan Derah Kabupaten Sidoarjo Nomor 3 Tahun 2016 Tetnag Penataan dan Pemberdayaan Pedagang Kaki Lima peran Bupati sebagai Kepala Daerah memiliki kewajiban untuk menyampaikan laporan hasil pelaksanaan penataan dan pemberdayaan pedagang kaki lima (PKL) kepada Gubernur.

\section{Wewenang Pemerintah Daerah Dalam Penegakan Hukum Administrasi}

Konsep kewenangan atau wewenang dianggap sangat penting dalam hukum administrasi, pada wewenang selalu menjadi bagian penting sebagai bagian awal dari hukum administrasi, dalam hal ini obyek hukum administrasi adalah sebuah wewenang pemerintahan (bestuurs bevoegheid). Dalam konsep hukum publik, wewenang merupakan suatu konsep inti hukum tata negara dan hukum administrasi. Oleh karenanya wewenang dalam perspektif HukumAdministrasi lebih kecil ranahnya dibandingkan dengan Hukum Tata Negara. Karena dalam Hukum Administrasi wewenang fokusnya pada tindakan pemerintah di ranah badan eksekutif. ${ }^{19}$

Suatu wewenang dalam penerapan sanksi administrasi pada dasarnya merupakan suatu wewenang untuk bertindak atau tidak melakukan suatu tindakan atas dasar penilaian sendiri dalam menjalankan suatu kewajiban hukum, dalam hal ini dapat dikenal dengan "discretionary power".

Berdasarkan pada pilar utama negara hukum yaitu menggunakan asas legalitas (legaliteits beginselen atau wetmatigheid van bestuur), asas tersebut digunakan sebagai prinsip daar bahwa wewenang pemerintah berasal dari ketentuan

${ }^{19}$ F. A. M. Stroink, Inleiding in Het Staats-en Administratief Recht (Samson H.D. Tjeenk Willink 1985).[26]. 
peraturan perundang-undangan. Dalam kepustakaan hukum administrasi terdapat dua cara untuk memperoleh wewenang pemerintahan, yaitu dengan cara atribusi dan delegasi, kadang kala mandat dapat ditempatkan sebagai cara tersendiri untuk memperoleh suatu wewenang pemerintahan. ${ }^{20}$

Memperoleh wewenang secara atribusi menunjuk pada kewenangan yang asli yang berdasarkan pada ketentuan hukum tata negara dan hukum administrasi. Atribusi adalah salah satu jenis wewenang untuk membuat keputusan (besluit) yang didasarkan pada peraturan perundang-undangan dalam arti materiil. Yang dapat membentuk wewenang adalah organ yang berwenang berdasarkan ketentuan peraturan perundang-undangan. ${ }^{21}$

Kewenangan yang sumber wewenangnya yakni delegasi adalah sumber kewenangan dimana pelimpahan wewenang yang diberikan kepada badan pemerintahan lain, delegasi dapat diartikan sebagai pelimpahan wewenang (untuk membuat "besluit") oleh pejabat pemerintahan kepada pihak lain dan wewenang tersebut menjadi tanggung jawab pihak tersebut. ${ }^{22}$ Terjadinya suatu pendelegasian oleh delegans (pemberi delegasi) kepada delegataris (penerima delegasi) selalu didahului oleh adanya suatu atribusi suatu wewenang. ${ }^{23}$ Jika konsep delegasi seperti itu, maka tidak ada delegasi umum dan tidak mungkin ada pendelegasian dari atasan ke bawahan. Atibusi merupakan pengenaan penyerahan wewenang baru, sedangkan delegasi menyangkut pelimpahan wewenang yang telah ada (oleh organ yang telah memperoleh wewenang secara atributif kepada organ lain).

Kepala daerah memberikan mandat kepada dinas terkait untuk menjalankan prosedur penataan dan pengendalian pedagang kaki lima (PKL) melalui keputusan tata usaha negara (TUN) yang dapat dibatalkan oleh kepala daerah sendiri apabila tidak dijalankan sesuai dengan yang semestinya. Asas Ius Contrarius Actus

\footnotetext{
${ }^{20}$ Philipus M. Hadjon, III. Lot.Cit. Lihat pada pendapat dari F.A.M. Stroink dan J.G. Steenbeek, Op.Cit.[40] yang menyatakan "Er bestaan slechts tweewijzen waarop een organ aan een bevoegheid kan komen, nomelijk attributie en delegatie".

21 ibid.[43].

22 J.B.J.M ten Berge dalam Philipus M. Hadjon I, Op.Cit.[4].

23 Nur Basuki Minarno, Penyalahgunaan Wewenang Dan Tindak Pidana Korupsi Dalam Pengelolaan Keuangan Daerah, (Laksbang Mediatama 2009).[72].
} 
merupakan sebuah asas yang menyatakan bahwa badan atau pejabat tata usaha negarayang menerbitkan keputusan TUN dengan sendirinya juga berwenang untuk membatalkannya. ${ }^{24}$

Pada pengaturan pedagang kaki lima (PKL) yang dilakukan oleh pemerintah daerah, pendelegasian wewenang kepada satuan kerja pemerintah daerah (SKPD) bertujuan sebagai bentuk koordinasi dalam melakukan tindakan penegakan hukum administrasi. Pemerintah daerah mendelegasikan kepada kepala dinas terkait untuk melaksanakan tugas tersebut. Dalam melaksanakan kewenangan guna menegakkan Peraturan Daerah, maka tugas ini diserahkan kepada Satuan Polisi Pamong Praja (Satpol PP). Pada Pasal 1 angka 5 Peraturan Pemerintah No. 10 Tahun 2004 Tentang Satuan Polisi Pamong Praja dijelaskan bahwa Polisi Pamong Praja merupakan aparatur Pemerintah Daerah yang melaksanakan tugas Kepala Daerah dalam memelihara dan menyelenggarakan ketenteraman dan ketertiban umum, menegakan sebuah Peraturan Daerah dan Keputusan Kepala Daerah.

\section{Pertanggungjawaban Wewenang}

Dalam hal wewenang, pejabat pemerintahan yang mendapatkan kewenangan untuk membuat keputusan harus bertanggungjawab secara yuridis terhadap penggunaan wewenang. Terjadinya penggunaan kewenangan yang melanggar hukum harus dilihat dari sumber atau lahirnya wewenang tersebut. Hal ini sesuai dengan konsep hukum "geen bevoegheid zonder verantwoordelijkheid atau there's no authority without responsibility". Dalam setiap pemberian wewenang kepada pejabat pemerintah tertentu tersirat pertanggung jawaban hukum dari pejabat pemerintah yang bersangkutan..$^{25}$

Pertanggung jawaban mandat bersumber dari persoalan wewenang, karena wewenang tetap berada pada pemberi wewenang, sedangkan penerima wewenang hanya dilimpahi wewenang dan bertindak untuk atas nama pemberi wewenang.

${ }^{24} \mathrm{Nn}$, Arti Asas Contrarius Actus https://www.hukumonline.com/klinik/detail/ulasan/lt5a4091a9d6c08/arti-asas-icontrarius-actus-i/, diakses pada 15 Juli 2020

${ }_{25}$ Nur Basuki Minarno, Op.Cit.[72-79]. 
Terhadap mandat tidak terjadi penyerahan wewenang, maka pemberi wewenang tetap dapat bertindak sendiri dan dengan namanya sendiri. Tidak adanya penyerahan mandate maka pertanggung jawaban yuridis tetap pada pemberi wewenang.

Dalam hukum administrasi setiap penggunaan wewenang mengandung pertanggung jawaban, namun harus dipisahkan mengenai tata cara untuk memperoleh dan menjalankan kewenangan tersebut, tidak semua pejabat yang menjalankan wewenang pemerintahan itu secara otomastis memikul tanggung jawab hukum. Pejabat pemerintahan yang memperoleh dan menjalankan wewenang secara atribusi dan delegasi adalah pihak yang melaksanakan tugas dan/atau pekerjaan atas dasar mandat bukanlah pihak yang memikul pertanggung jawaban hukum.

Pada kasus sering terjadi di dalam kegiatan penertiban oleh Satuan Polisi Pamong Praja (Satpol PP) yang mengakibatkan permasalahan rusaknya barang yang dimiliki oleh pedagang kaki lima. Dalam hal ini, pertanggungjawaban wewenang dilaksanakan secara pribadi oleh petugas yang berada di lapangan saat terjadi penertiban, sehingga bukan tanggungjawab instansi Satuan Polisi Pamong Praja (Satpol PP) jika terjadi kerusakan dan jika suatu barang milik pedagang mengalami kerusakan sebelum terjadinya penertiban, maka menjadi pertanggungjawaban pribadi dari pedagang tersebut.

\section{Kesimpulan}

Tindakan penataan Pedagang Kaki Lima (PKL) oleh Pemerintah Daerah dilakukan dengan mengedepankan Asas-asas Pemerintahan Umum yang Baik (AUPB) untuk menjamin keselarasan pada sebuah sistem kegiatan usaha (berdagang) yang dilakukan oleh pedagang kaki lima (PKL) agar dapat berjalan dengan tertib dan mengantisipasi adanya segala bentuk praktik-praktik pelanggaran, seperti melakukan sebuah usaha di lahan yang tidak sesuai peruntukannya, pencemaran lingkungan akibat limbah usaha, serta menyebabkan gangguan pada pengguna fasilitas umum.

Penegakan hukum yang dilakukan oleh Pemerintah Daerah dilakukan untuk membenahi ketertiban para pedagang dalam menjalankan kegiatan usahanya agar 
lebih tertata dan tertib. Pendelegasian wewenang kepada satuan kerja pemerintah daerah (SKPD) bertujuan sebagai bentuk koordinasi dalam melakukan tindakan penegakan hukum administrasi. Pemerintah daerah mendelegasikan kepada kepala dinas terkait untuk melaksanakan tugas tersebut. Dalam melaksanakan kewenangan guna menegakkan Peraturan Daerah, maka tugas ini diserahkan kepada Satuan Polisi Pamong Praja (Satpol PP). Pada Pasal 1 angka 5 Peraturan Pemerintah No. 10 Tahun 2004 Tentang Satuan Polisi Pamong Praja

\section{Daftar Bacaan}

\section{Buku}

,Analisa dualistik dan faktor yang menyebabkan sektor ekonomi informal hal. 1-2. Lihat juga konsep Negara Hukum Walfare State oleh Moh. Mahfud M.D., Hukum dan Pilar-Pilar Demokrasi (Gama Media 1999).

F. A. M. Stroink, Inleiding in Het Staats-en Administratief Recht (Samson H.D. Tjeenk Willink 1985).

Jum Anggriani, Hukum Administrasi Negara (Graha Ilmu 2012).

Nur Basuki Minarno, Penyalahgunaan Wewenang Dan Tindak Pidana Korupsi Dalam Pengelolaan Keuangan Daerah, (Laksbang Mediatama 2009).

Philipus M. Hadjon, Ide Negara Hukum, (Makalah yang disampaikan pada Seminar Hukum Administrasi, Fakultas Hukum Universitas Airlangga 2004).

Philipus M Hadjon, ‘Tentang Wewenang’ (1990) III No. 5 dan 6 Yuridika.

Revrisond Baswir, Tiada Ekonomi Kerakyatan Tanpa Kedaulatan Rakyat, dalam Baswir (1997), Agenda Ekonomi Kerakyatan (Pustaka Pelajar 2000).

Richard Burton Simatupang, Aspek Hukum Dalam Bisnis (Rineka Cipta 1996).

Ridwan HR, Hukum Administrasi Negara (Rajawali Pers 2016).

Tatiek Sri Djatmiati, Prinsip Izin Usaha Industri di Indonesia (Disertasi, Program Pascasarjana Universitas Airlangga 2004).

Tulus Tambunan, Usaha Mikro, Kecil, dan Menengah Di Indonesia: Isu-Isu Penting, (LP3ES 2012). 


\section{Laman}

Arti Asas Contrarius Actus https://www.hukumonline.com/klinik/detail/ulasan/ 1t5a4091a9d6c08/arti-asas-icontrarius-actus-i/, diakses pada 15 Juli 2020.

Cut Husnul, Pedagang Kaki Lima, https://www.academia.edu/29520984/ PEDAGANG_KAKI_LIMA, dikunjungi pada tanggal 15 Mei 2019.

Mekanisme Penerbitan Surat Izin Usaha Mikro Kecil, https://www.finansialku. com/surat-izin-usaha-mikro-kecil/, diakses pada 3 April 2020.

Pengertian Preventif dan Represif, Contoh tujuan tindakan preventif dan represif, https://www.maxmanroe.com/vid/umum/pengertian-preventif.html dikunjungi pada tanggal 1 Juni 2019.

Penggunaan Wewenang Menurut Hukum, https://hehim29.blogspot.com/2011/04/ penggunaan-wewenang-menurut-hukum-dan.html?m=1 dikunjungi pada 1 Juni 2019.

Pengertian Pengendalian (Controliing) dan Empat Langkah Pengendalian https:// ilmumanajemenindustri.com/pengertian-pengendalian-controlling-empatlangkah-pengendalian/, diakses pada 13 Juli 2020 pukul 11.22.

PREVENTIF DAN REPRESIF : Pengertian Preventif dan Represif, Contoh, Beserta Tujuannya, https://pendidikan.co.id/preventif-dan-represif/, diakses pada12 Maret 2020.

Usaha Mikro: Klasifikasi, Dasar Hukum dan Kewajiban Perpajakan, https://www. online-pajak.com/usaha-mikro, diakses pada 12 Februari 2020.

Wawancara Ibu Cucuk S. http://digilib.uinsby.ac.id/15826/49/Bab\%204.pdf, diakses pada Senin 4 Mei 2020. 23:41 WIB. 
Bayu Ariefka: Penataan dan Pengendalian

--halaman ini sengaja dibiarkan kosong-- 